\title{
Sequence Analysis of the Tumor Necrosis Factor Gene in Pediatric Patients with Autoimmunity
}

\author{
LISA BECKER, TRACY BROWN, CHESTER FINK, JAMES MARKS, GERALD LAVANDOSKY, \\ AND BRETT P. GIROIR \\ The Laboratories for Molecular Biology and Physiology Research, The Department of Pediatrics, \\ University of Texas Southwestern Medical Center, Dallas, Texas 75235-9063
}

\section{ABSTRACT}

TNF $3^{\prime}$-untranslated region was amplified by the polymerase chain reaction, sequenced, and analyzed relative to the published TNF sequence. In this study, all patients and controls exhibited the normal sequence, with no insertions or deletions in the translational control motifs. We conclude that polymorphisms in the TNF $3^{\prime}$-untranslated region occur infrequently, if at all, in patients with diseases examined here. (Pediatr Res 37: 165-168, 1995)
TNF, tumor necrosis factor- $\alpha$
$3^{\prime}$-UTR, $3^{\prime}$ untranslated region
RA, rheumatoid arthritis
PCR, polymerase chain reaction

Abbreviations
TNF is a pluripotent cytokine, encoded in the MHC, which mediates inflammatory responses (1-5). Appropriately regulated, TNF biosynthesis is critically important to host defense (6) and immune ontogeny $(7,8)$. However, dysregulated TNF production may lead to the development of autoimmunity, as evidenced by recent data from animal models and patients. In type I diabetes mellitus, TNF potentiates IL-1-mediated islet cell toxicity in vitro and enhances interferon-induced HLA class II gene expression on islet cells $(9,10)$. Furthermore, overexpression of TNF in the pancreatic islets of transgenic mice results in chronic lymphocytic insulitis $(11,12)$. Dysregulated TNF production has also been implicated in the pathogenesis of RA. Elevated TNF levels are present in the joint fluid of RA patients (13) and may promote cartilage breakdown by chondrocytes and bone resorption by osteoclasts $(14,15)$.

Given these associations, several investigators have speculated that mutations within the TNF gene might account for the MHC-linked components of diabetes, RA, and other autoimmune diseases $(16,17)$. Indeed, interindividual variations in TNF secretory capacity have recently been correlated with HLA haplotypes, restriction fragment length polymorphisms,

Received April 13, 1994; accepted September 1, 1994.

Correspondence: Dr. Brett P. Giroir, The University of Texas Southwestern Medical Center, 5323 Harry Hines Blvd., Dallas, TX 75235-9063. and TNF microsatellites (18-20). Presumably, these genetic markers reflect the existence of TNF alleles with mutations in the regulatory regions of the TNF gene. Among these regulatory regions is the TNF $3^{\prime}$-UTR, which powerfully regulates TNF expression at the level of translation $(3,21,22)$. Evolutionarily conserved motifs ("TTATTTAT" sequences) in the TNF $3^{\prime}$-UTR were shown to have two functions: to shorten the TNF mRNA half-life (23) and to suppress translation of TNF mRNA during normal conditions (24). When Keffer et al. (25) replaced these translational regulatory sequences with irrelevant sequences from the $3^{\prime}$-UTR of the $\beta$-globin gene, the resulting transgenic mice displayed aberrant TNF production and developed chronic inflammatory polyarthritis. Recently, insertional mutations were found in the TNF 3 '-UTR "TTATTTAT" sequences of New Zealand White mice, which are known to bear an MHC-linked gene implicated in the development of murine systemic lupus erythematosus (26). These data further suggest that polymorphisms in the TNF translational control region may be associated with the development of autoimmunity in certain controlled systems.

Inasmuch as the TNF $3^{\prime}$-UTR is an important regulator of TNF biosynthesis and is associated with autoimmune conditions in animal models, we undertook our study to determine whether mutations in the TNF $3^{\prime}$-UTR were present in pediatric patients with autoimmunity. Based on animal models and 
known associations of human TNF polymorphisms with autoimmune diseases, we chose type I diabetes mellitus and juvenile arthritis as the primary diseases for study.

\section{METHODS}

Patient selection. The experimental protocol was approved by the Institutional Review Board for Human Research at the University of Texas Southwestern Medical Center. Pediatric patients with or without autoimmune syndromes were recruited from the outpatient and inpatient populations at Children's Medical Center, Parkland Memorial Hospital, and Texas Scottish Rite Hospital, Dallas.

Genomic DNA purification. A $500-\mu \mathrm{L}$ blood sample was collected in Ca-EDTA specimen tubes from each patient enrolled in the study. Cellular elements were pelleted by centrifugation for $10 \mathrm{~s}$ at $10000 \times \mathrm{g}$; pellets were washed twice for $10 \mathrm{~s}$ in $500 \mu \mathrm{L}$ of a solution consisting of $10 \mathrm{mM}$ Tris, $1 \mathrm{mM}$ EDTA, pH 8. Pellets were then resuspended in $100 \mu \mathrm{L}$ of a solution containing $0.5 \%$ Tween $20,50 \mathrm{mM} \mathrm{KCl}, 10 \mathrm{mM}$ Tris, $\mathrm{pH} 8.3$, and $2.5 \mathrm{mM} \mathrm{MgCl}_{2}$. Fifteen $\mu \mathrm{g}$ of Proteinase K (Sigma Chemical Co., St. Louis, MO) were then added and incubated for $1 \mathrm{~h}$ at $60^{\circ} \mathrm{C}$. The samples were then heated to $100^{\circ} \mathrm{C}$ for 10 $\min$; a $10-\mu \mathrm{L}$ aliquot of this solution was next subjected to PCR amplification.

PCR. A 250-bp segment of the TNF 3' UTR was amplified using Vent polymerase (New England Biolabs, Boston, MA) and primers with the sequences $5^{\prime}$-CCCGAGCTCTTAGGCCTTCCTCTCTCCAGA containing an upstream SacI site and 5'-CCCGGATCCGTTCAGCTCCGTTTTCACGGA containing a downstream Bam $\mathrm{HI}$ site. The designed restriction sites of the oligonucleotide primers allowed for ligation of amplified fragments into the vector pGEM $3 Z$ (Promega Biotec, Madison, WI) for sequencing. Clones containing the 250-bp insert were then sequenced by the Sanger dideoxynucleotide chain termination method using M13 universal primers that match vector sequence flanking the fragment cloning site.

\section{RESULTS}

A total of 109 patients and volunteers were enrolled into the study, 80 of whom were diagnosed with connective tissue diseases or type I diabetes. The clinical diagnoses supplied by the patients' attending physicians are listed in Table 1. A 250-bp segment of the TNF 3 'UTR containing the known TNF translational regulatory sequences (Fig. 1) was amplified by

Table 1. Clinical diagnoses of patients undergoing TNF sequence analysis

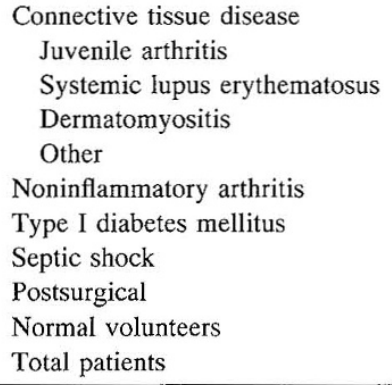

2954 TTAGGCCTTCCTCTCTCCAGATGTTTCCAGACTTCCTTGAGACACGGA GCCCAGCCCTCCCCATGGAGCCAGCTCCCTCTATTTATGTTTGCACT1 GTGAITATTTATTATITATTTATTATITATTTATTTACAGATGAATGT ATTTATTTGGGAGACCGGGGTATCCTGGgGGACCCAATGTAGGAGCT CCTTGGCTCAGACATGTTTTCCGTGAAAACGGAGCTGAAC 3185

Figure 1. Amplified segment of the human TNF $3^{\prime}$-UTR. Octameric "TTATTTAT" translational control sequences are underlined.

PCR and subcloned; a minimum of four clones from each PCR were sequenced. Two additional PCR amplifications followed by subcloning and sequencing were done on samples that initially appeared to display mutations to eliminate PCR or sequencing artifact. In this study, all patients and controls exhibited the normal, wild-type sequence, with no evident deletions or insertions in the "TTATTTAT" sequences or other TA-rich motifs.

\section{DISCUSSION}

Clinical and experimental evidence suggest that dysregulated TNF biosynthesis is important in the pathogenesis of certain autoimmune conditions. In patients with RA, TNF levels are elevated in both the systemic circulation and the synovial fluid obtained from diseased joints $(13,27)$. In situ hybridization and immunochemistry have localized TNFproducing cells to the cartilage-pannus junction, which is the leading edge of tissue destruction in affected joints $(28,29)$. In experimental models, instillation of TNF and IL-1 into the synovial joint space causes leukocyte infiltration, prostaglandin secretion, cartilage destruction, and bone resorption (30). These and other data have led to clinical trials of MAb directed against TNF in patients with autoimmune arthritis; a recent open label phase I/II trial demonstrated significant therapyassociated improvements in Ritchie articular index, swollen joint count, and biochemical parameters of inflammation (31).

Data from animal models and from humans also implicate dysregulated TNF biosynthesis and secretion in the pathogenesis of type I diabetes mellitus, although the precise mechanisms of TNF action are debatable. TNF may be produced by pancreatic islet cells (32) or by lymphocytes that infiltrate the islets during the course of acute insulitis (33). TNF may be directly toxic to islet cells or may be indirectly injurious by enhancing IL-1 toxicity, up-regulating MHC class II gene expression, or inducing islet secretion of IL-6 (9, 10, 34-38). In contrast to local proinflammatory properties of TNF secreted within the islets, it is well established that nonobese diabetic mice profoundly underproduce TNF in response to provocative stimuli (26); in these animals and in the diabetes-prone BB rat, long-term administration of TNF significantly reduces the severity and incidence of diabetes $(39,40)$.

Theoretically, the association between abnormal patterns of TNF production and the development of autoimmunity may be 
explained by three hypotheses: 1) TNF secretion may be a nonetiologic epiphenomenon. This explanation is the least likely given the accumulation of current data. 2) TNF may be an inflammatory effector of an otherwise unrelated genetic susceptibility. 3) Abnormalities in TNF regulation may directly lead to disease pathogenesis.

If primary dysregulation of TNF production were causative of autoimmunity, then traditional MHC-disease associations may reflect mutations within the TNF locus itself. Consistent with this hypothesis are provocative data recently reported by several investigators. TNF secretory capacity in humans was shown to correlate with several genetic markers including HLA haplotypes (41), TNF- $\beta$ NcoI restriction fragment length polymorphisms (42), and TNF microsatellites (18). Diabetesassociated haplotypes carry an allele that correlates with high TNF secretory capacity, with $\mathrm{DR} 3^{+}$and $\mathrm{DR} 4^{+}$patients being the highest TNF responders. Furthermore, DR3/4 heterozygous diabetic patients have a significant increase in the frequency of $\mathrm{TNFa} 2$ microsatellite compared with DR3/4 individuals without diabetes who possess the TNFa6 microsatellite allele (18).

The search for mutations in the TNF gene that might account for these allelic associations is currently under way. Wilson $e t$ al. (43) reported an allelic polymorphism at position -308 of the TNF promoter, which is associated with the autoimmuneprone human HLA haplotype A1,B8,DR3. However, no functional significance to this polymorphism has yet been established (44). In addition, a polymorphic variation in the putative "Y box" of the TNF promoter has been described by D'Alfonso and Richiardi (45). Recently, attention has also been directed to the TNF $3^{\prime}$-UTR and in particular the octameric "TTATTTAT" motifs therein, which govern TNF mRNA stability (23) and translational efficiency (3). Substitution of the TNF $3^{\prime}$-UTR by a $\beta$-globin $3^{\prime}$-UTR resulted in transgenic mice that displayed inflammatory polyarthritis; this arthritis was eliminated by administration of MAb directed at TNF from the time of the animal's birth (25). Most recently, Jacob and Tashman (26) and Beutler and Brown (46) have simultaneously reported insertional mutations in the "TTATTTAT" sequences of New Zealand White mice, which are known to carry an MHC-linked gene implicated in the development of murine lupus. In addition, Jacob (16) demonstrated that the presence of this insertion in New Zealand White mice and three other murine strains closely correlated with a decreased TNF secretory capacity to provocative stimulation.

Our study is the first to specifically examine the $3^{\prime}$-UTR in humans with autoimmunity. We initially chose patients with diabetes and juvenile arthritis because of the widespread evidence suggesting TNF's pathogenic importance in these conditions. Sequence analysis of the TNF $3^{\prime}$-UTR in 109 patients and controls indicated that polymorphisms in this region occur infrequently, if at all, in the patient populations we examined. It remains possible that such mutations may occur in other autoimmune diseases not examined in this report, or in a very small percentage of patients with diabetes and arthritis. It is also possible that such mutations do not exist at all in humans. Additional studies should be done to distinguish among these possibilities.

\section{REFERENCES}

1. Tracey KJ, Beutler B, Lowry SF 1986 Shock and tissue injury induced by recombinant human cachectin. Science 234:470-474

2. Beutler B, Milsark IW, Cerami A 1985 Passive immunization against cachectin/tumor necrosis factor (TNF) protects mice from the lethal effect of endotoxin. Science 229:869-871

3. Beutler B, Han J, Kruys V, Giroir BP 1992 Coordinate regulation of TNF biosynthesis at the levels of transcription and translation. In: Beutler B (ed) Tumor Necrosis Factors. Raven Press, New York, pp 561-574

4. Darville T, Giroir BP, Jacobs R 1993 The systemic inflammatory response syndrome (SIRS): immunology and potential immunotherapy. Infection 21:279-290

5. Damas P, Reuter A, Gysen P, Demonty J, Lamy M, Franchimont P 1989 Tumor necrosis factor and interleukin-1 serum levels during severe sepsis in humans. Crit Care Med 17:975-978

6. Havell EA 1989 Evidence that tumor necrosis factor has an important role in antibacterial resistance. J Immunol 143:2894-2899

7. Giroir BP, Brown T, Beutler B 1992 Constitutive synthesis of tumor necrosis factor in the thymus. Proc Natl Acad Sci USA 89:4864-4868

8. Kossodo S, Grau GE, Daneva T, Pointaire P, Fossati L, Ody C, Zapf J, Piguet P-F, Gaillard RC, Vassalli P 1992 Tumor necrosis factor alpha is involved in mouse growth and lymphoid tissue development. J Exp Med 176:1259-1264

9. Wright JR, Epstein HR, Hauptfeld V, Lacy PE 1988 Tumor necrosis factor enhances interferon-induced Ia antigen expression on murine islet parenchymal cells. Am J Pathol 130:427-430

10. Nerup J, Mandrup-Poulsen T, Molvig J, Helqvist S, Wogensen L, Egeberg J 1988 Mechanisms of pancreatic beta-cell destruction in type I diabetes. Diabetes Care $11: 16-23$

11. Higuchi Y, Herrera P, Muniesa P, Huarte J, Belin D, Ohashi P, Aichele P, Orci L, Vassali J-D, Vassalli P 1992 Expression of a tumor necrosis factor-alpha transgene in murine pancreatic beta cells results in severe and permanent insulitis without evolution towards diabetes. J Exp Med 176:1719-1731

12. Picarella DE, Kratz A, Li C, Ruddle NH, Flavell RA 1993 Transgenic tumor necrosis factor (TNF)-alpha production in pancreatic islets leads to insulitis, not diabetes. J Immunol 150:4136-4150

13. Saxne T, Palladino MA, Heinegard D, Talal N, Wollheim FA 1988 Detection of tumor necrosis factor alpha but not tumor necrosis factor beta in rheumatoid arthritis synovial fluid and serum. Arthritis Rheum 31:1041-1045

14. Saklatvala J 1986 Tumour necrosis factor alpha stimulates resorption and inhibits synthesis of proteoglycan in cartilage. Nature 322:547-549

15. Thomas BM, Mundy GR, Chambers TJ 1987 Tumor necrosis factor alpha and beta induce osteoblastic cells to stimulate osteoclast bone resorption. J Immunol 138:775-780

16. Jacob CO 1993 Genetic variability in tumor necrosis factor production: relevance to predisposition to autoimmune disease. Region Immunol 4:298-304

17. Verjans GMGM, Messer G, Weiss EH, van der Linden SM, Kijlstra A 1992 Polymorphism of the tumor necrosis factor region in relation to disease: an overview. Rheum Dis Clin North Am 18:177-186

18. Pociot F, Briant L, Jongeneel CV 1993 Association of tumor necrosis factor (TNF) and class II major histocompatibility complex alleles with the secretion of TNF-alpha and TNF-beta by human mononuclear cells: a possible link to insulin-dependent diabetes mellitus. Eur J Immunol 23:224-231

19. Dawkins RL, Leaver A, Cameron PU, Martin E, Kay PH, Christianse FT 1989 Some disease-associated ancestral haplotypes carry a polymorphism of TNF. Hum Immunol 26:91-97

20. Partanen J, Koskimies S 1988 Low degree of DNA polymorphism in the HLA-linked lymphotoxin (tumour necrosis factor beta) gene. Scand J Immunol 28:313-316

21. Han J, Huez G, Beutler B 1991 Interactive effects of the tumor necrosis factor promoter and $3^{\prime}$-untranslated regions. J Immunol 146:1843-1848

22. Han J, Beutler B 1990 The essential role of the UA-rich sequence in endotoxininduced cachectin/TNF synthesis. Eur Cytokine Netw 1:71-75

23. Shaw G, Kamen R 1986 A conserved AU sequence from the $3^{\prime}$ untranslated region of GM-CSF mRNA mediates selective mRNA degradation. Cell 46:659-667

24. Han J, Brown T, Beutler B 1990 Endotoxin-responsive sequences control cachectin/ tumor necrosis factor biosynthesis at the translational level. J Exp Med 171:465-475

25. Keffer J, Probert L, Cazlaris H, Georgopoulos S, Kaslaris E, Kioussis D, Kollias G 1991 Transgenic mice expressing human tumour necrosis factor: a predictive genetic model of arthritis. EMBO J 10:4025-4031

26. Jacob CO, Tashman NB 1993 Disruption in the AU motif of the mouse TNF alpha $3^{\prime}$ UTR correlates with reduced TNF production by macrophages in vitro. Nucleic Acids Res 21:2761-2766

27. Danis VA, Franic GM, Rathjen DA, Laurent RM, Brooks PM 1992 Circulating cytokine levels in patients with rheumatoid arthritis: results of a double blind trial with sulphasalazine. Ann Rheum Dis 51:946-950

28. Deleuran BW, Chu CQ, Field M, Brennan FM, Mitchell T, Feldmann M, Maini RN 1992 Localization of tumor necrosis factor receptors in the synovial tissue and cartilage-pannus junction in patients with rheumatoid arthritis. Arthritis Rheum 35:1170-1178

29. Chu CQ, Field M, Feldman M, Maini RN 1991 Localization of tumour necrosis factor alpha in synovial tissues and the cartilage pannus junction in patients with rheumatoid arthritis. Arthritis Rheum 34:1125-1132

30. Brennan FM, Maini RN, Feldmann M 1992 TNF: a pivotal role in rheumatoid arthritis? Br J Rheumatol 31:293-298

31. Elliott MJ, Maini RN, Feldmann M, Long-Fox A, Charles P, Katsikis P, Brennan FM, Walker J, Bijl H, Ghrayeb J, Woodby JN 1993 Treatment of rheumatoid arthritis with chimeric monoclonal antibodies to tumor necrosis factor alpha. Arthritis Rheum 36:1681-1690 
32. Giroir BP, Johnson JH, Brown T, Allen GA, Beutler B 1992 The tissue distribution of tumor necrosis factor biosynthesis during endotoxemia. J Clin Invest 90:693-698

33. Held W, MacDonald HR, Weissman IL, Hess MW, Mueller C 1990 Genes encoding tumor necrosis factor and granzyme A are expressed during development of autoimmune diabetes. Proc Natl Acad Sci USA 87:2239-2243

34. Mandrup-Poulsen T, Bendtzen K, Dinarello CA, Nerup J 1987 Human tumor necrosis factor potentiates human interleukin-1-mediated rat pancreatic beta-cell cytotoxicity. J Immunol 139:4077-4082

35. Bendtzen K, Mandrup-Poulsen T, Nerup J, Nielsen JH, Dinarello CA, Svenson M 1986 Cytotoxicity of human pI 7 interleukin-1 for pancreatic islets of Langerhans. Science 232:1545-1547

36. Campbell IL, Kay TWH, Oxbrow L, Harrison LC 1992 Essential role for interferongamma and interleukin-6 in autoimmune insulin-dependent diabetes in NOD/Wehi mice. J Clin Invest 87:739-742

37. Campbell IL, Cutri A, Wilson A, Harrison LC 1989 Evidence for IL-6 production by and effects on the pancreatic B-cell. J Immunol 143:1188-1191

38. Mandrup-Poulsen T, Bendtzen K, Nerup J, Dinarello CA, Svenson M, Nielsen JH 1986 Affinity-purified human interleukin 1 is cytotoxic to isolated islets of Langerhans. Diabetologia 29:63-67

39. Jacob CO, Aiso S, Michie SA, McDevitt HO, Acha-Orbea H 1990 Prevention of diabetes in nonobese diabetic mice by tumor necrosis factor (TNF): similarities between TNF-alpha and interleukin 1. Immunology 87:968-972
40. Satoh J, Seino H, Abo T, Tanaka S, Shintani S, Ohta S, Tamura K, Sawai T, Nobunaga T, Oteki T, Kumagai K, Toyota T 1989 Recombinant human tumor necrosis factor alpha suppresses autoimmune diabetes in nonobese diabetic mice. J Clin Invest 84:1345-1348

41. Jacob CO, Fronek Z, Lewis GD, Koo M, Hansen JA, McDevitt HO 1990 Heritable major histocompatibility complex class II associated difference in production of tumor necrosis factor-alpha: relevance to genetic predisposition to systemic lupus erythematosus. Proc Natl Acad Sci USA 87:1233-1237

42. Pociot F, Molvig J, Wogensen L, Worsaae H, Dalboge H, Baek L, Nerup J 1991 A tumor necrosis factor beta gene polymorphism in relation to monokine secretion and insulin dependent diabetes mellitus. Scand J Immunol 33:37-49

43. Wilson AG, de Vries N, Pociot F, di Giovine FS, van der Putte LBA, Duff GW 1993 An allelic polymorphism within the human tumor necrosis factor alpha promoter region is strongly associated with HLA A1, B8, and DR3 alleles. J Exp Med $177: 557-560$

44. Pociot F, Wilson AG, Nerup J, Duff GW 1993 No independent association between a tumor necrosis factor-alpha promotor region polymorphism and insulin-dependent diabetes mellitus. Eur J Immunol 23:3050-3053

45. D'Alfonso S, Richiardi PM 1994 A polymorphic variation in a putative regulation box of the TNFA promoter region. Immunogenetics 39:150-154

46. Beutler B, Brown T 1993 Polymorphism of the mouse TNF- $\alpha$ locus: sequence studies of the $3^{\prime}$-untranslated region and first intron. Gene 129:279-283 